Discussion Paper No. 18-058

\title{
Using Emissions Trading Schemes to Reduce Heterogeneous Distortionary Taxes: the Case of Recycling Carbon Auction Revenues to Support Renewable Energy
}

Claire Gavard, Sebastian Voigt, and Aurélien Genty

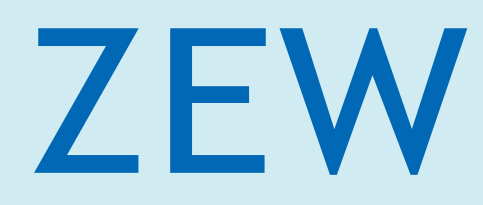

Zentrum für Europäische Wirtschaftsforschung $\mathrm{GmbH}$ Centre for European Economic Research 
Discussion Paper No. 18-058

\section{Using Emissions Trading Schemes to Reduce Heterogeneous Distortionary Taxes: the Case of Recycling Carbon Auction Revenues to Support Renewable Energy}

Claire Gavard, Sebastian Voigt, and Aurélien Genty

Download this ZEW Discussion Paper from our ftp server:

http://ftp.zew.de/pub/zew-docs/dp/dp18058.pdf

Die Discussion Papers dienen einer möglichst schnellen Verbreitung von neueren Forschungsarbeiten des ZEW. Die Beiträge liegen in alleiniger Verantwortung der Autoren und stellen nicht notwendigerweise die Meinung des ZEW dar.

Discussion Papers are intended to make results of ZEW research promptly available to other economists in order to encourage discussion and suggestions for revisions. The authors are solely responsible for the contents which do not necessarily represent the opinion of the ZEW. 


\section{Using Emissions Trading Schemes to Reduce Heterogeneous Distortionary Taxes: the case of Recycling Carbon Auction Revenues to support Renewable Energy}

Claire Gavard, ${ }^{\mathrm{a}, *}$ Sebastian Voigt ${ }^{\mathrm{b}}$ and Aurélien Genty ${ }^{\mathrm{c}}$

${ }^{a}$ Centre for European Economic Research (ZEW), L7, 1, D-68161 Mannheim, Germany; Claire.Gavard@zew.de

${ }^{\mathrm{b}}$ Centre for European Economic Research (ZEW), L7, 1, D-68161 Mannheim, Germany; Sebastian.Voigt@zew.de

${ }^{\mathrm{c}}$ European Commission, B-1049 Brussels, Belgium; Aurelien.Genty@ec.europa.eu

*Corresponding author, Claire.Gavard@ zew.de, Ph: +49.621.1235.208, Fax: +49.621.1235.226. 


\begin{abstract}
While emissions trading schemes are developed by nations to mitigate their greenhouse gas emissions, behavioural studies have shown that the political and public acceptability of these market-based instruments depends on the way the associated revenues are used. One option the general public approves of is to use them to support renewable energy. If this consists in reducing a pre-existing electricity levy that heterogeneously applies to the various sectors of the economy, the reduction of this distortionary tax thanks to the carbon revenues results in general equilibrium effects that may have unequal sectoral impacts. This is what we examine in the case of the European Union. With a modelling approach including a detailed disaggregation of European sectors, we find that using auction revenues from the Emissions Trading Scheme (ETS) to support electricity generation from renewable sources results in a $2 \%$ rise in electricity demand in the whole economy due to the reduced electricity levy that electricity consumers have to pay to support renewable energy. This results in a 1.8\% ETS carbon price increase. The carbon constraint for the non-ETS sectors is $5.9 \%$ looser as a consequence of the larger electricity use by these sectors. While the energy intensive sectors generally benefit from electricity levy exemptions, we observe that, due to the energy and ETS price increase, the combination of these exemptions and of the use of carbon auction revenues to support renewable energy makes the ETS sectors worse off than if carbon revenues are transferred to households. In aggregate, the recycling option analysed here results in a GDP gain due to its impacts on the non-ETS sectors, the reduction of the electricity levy and associated distortionary effects.
\end{abstract}

\title{
Keywords:
}

Carbon auctions; renewable energy support; electricity levy; emissions trading scheme; revenues recycling.

\section{JEL classification:}

C68, E62, H21, H23, Q42, Q54

\section{INTRODUCTION}

Negative environment externalities may be corrected by policy instruments such as subsidies or taxes. Their efficiency respectively depends on the resources used to finance them and on how the corresponding revenues are used. Pigouvian taxes tend to be more efficient than subsidies as the associated revenues can be recycled to reduce other taxes (see Ballard and Medema, 1993). Despite this, the general public usually prefers subsidies, as shown for example by Heres et al. (2015). There are various reasons for this, one of which is the fact that the cost of the subsidy is less visible for the general public than a tax (Harrison, 2010). The public acceptability of taxes is improved if information is provided on how the corresponding revenues are used, and, in

particular, if they are earmarked for environmental purposes (Kallbekken et al, 2011; Kallbekken and Aasen, 2010). 
In the field of climate policy, this is particularly true for political debates regarding carbon pricing $^{1}$ vs. renewable energy (RE) or innovation support policies. Despite the fact that economists usually consider emissions trading schemes (ETS) as cost-efficient measures to reduce emissions, cap-and-trades are not always well perceived by politicians and the general public. That is visible in the United States, where several federal cap-and-trade proposals were discussed and analysed (e.g. by Gurgel et al., 2011), but never adopted. On the contrary, financial support for renewable energy or innovation benefits from a much higher political acceptability. Still, while supporting renewable energy may have various political objectives (e.g. climate policy, energy independence, competitiveness), it might be rather inefficient with regard to emissions reductions. Marcantonini and Ellerman (2015), for example, have computed the implicit abatement cost of renewable energy incentives in Germany and found that it might be substantially higher than an ETS price.

Behavioural studies have suggested that the public and political acceptability of carbon markets depends on the design of these schemes and in particular on the way the associated revenues are used. Vollebergh et al. (1997), for example, show that hybrid systems of grandfathering and auctions can improve the political acceptability of carbon pricing. Bristow et al. (2010) study the public acceptability of personal carbon trading in comparison with a carbon tax. The authors show that the initial permits allocation and the use made of the carbon revenues are important design features in this regard. ${ }^{2}$

It seems possible to improve the public acceptability of ETS's by actually using the carbon revenues for climate and energy purposes. One of these purposes could be the support of renewable energy deployment. In a way, this is a solution to the debate mentioned above on the ways to correct environmental externalities by combining carbon pricing and subsidies rather than opposing them. The economic impacts of such a recycling choice depends on the pre-existing RE policy framework. In particular, if the latter relies on the use of an electricity levy, employing the carbon revenues to reduce this tax is expected to result in efficiency gains. The aim of this paper is to analyse the economic consequences of using carbon revenues to support RE-based power generation, as a function of the specific characteristics of the pre-existing RE policy funding. It extends the literature on environmental taxation in the presence of other taxes (e.g. Bovenberg and Goulder, 1996; Nordhaus, 1993; Ballard and Medema, 1993) to carbon pricing in the form of an ETS, in the presence of a specific distortionary commodity tax - the electricity levy - that applies heterogeneously to the various sectors of the economy. While the efficiency loss associated with the use of a distortionary tax is well known, the benefit from reducing such a tax, thanks to the revenues from a Pigouvian tax when the application of the distortionary tax is heterogeneous among sectors, is worth being investigating. The general equilibrium effects that take place may

\footnotetext{
${ }^{1}$ An overview of carbon pricing instruments developed in the world is provided by World Bank and Ecofys (2018). In particular, carbon markets expand around the world with currently 21 operational emissions trading schemes covering around 7.4 billion tCO2e in 2018 (ICAP 2018).

${ }^{2}$ In line with these results, the survey analysis conducted by Amdur et al. (2014) showed that, in the US, for both democrats and republicans, the support for a carbon tax is significantly higher when the revenues are planned to be used for renewable energy support.
} 
indeed result in unequal sectoral benefits. This is what we examine in the context of an ETS instead of a Pigouvian tax.

Given the European experience in terms of carbon pricing and RE support policy, we take the European Union (EU) as a case study for our analysis. The EU ETS started in 2005 (EU, 2003). This instrument is the cornerstone of the EU climate and energy policy. The latter was specifically agreed upon by the EU leaders in the 2020 climate and energy package and then in the 2030 climate and energy framework (EC, 2014a). Together with the objective of a $40 \%$ reduction of greenhouse gas (GHG) emissions compared to 1990 levels, the agreement includes a target of $32 \%$ of renewable energy sources in energy consumption, and an overall goal of $32.5 \%$ energy savings compared with the business-as-usual trend. Member States are free to choose the instruments to support RE deployment: ${ }^{3}$ feed-in tariffs, premiums, green certificates, etc. Since 2013 companies have had to buy an increasing proportion of permits through auctions (EC, 2010). The amended EU ETS Directive (EU, 2009) stipulates Member States are free to decide how they use carbon auction revenues, but that they have to use at least $50 \%$ of the auction revenues for climate and energy related purposes. Among others, auction revenues can be used to support renewable energy. Depending on the way Member States fund their RE policy and given the fact that the electricity sector itself is covered by the ETS, we expect that the use of carbon auction revenues to subsidize RE-based power generation leads to general equilibrium effects that deserve to be examined. In most Member States, RE support is financed by an electricity levy (paid by electricity consumers, including some industries covered by the ETS), while in others (the United Kingdom, Poland and Finland) the funding comes from the general public budget (paid by tax payers). In this empirical context of the EU, the paper examines the economic impacts of such a recycling option on the whole economy ${ }^{4}$ and in particular on the various industrial sectors, depending on their energy intensities, the type of renewable energy support used and potentially associated exemption rules. After collecting and combining detailed sectoral level data on the EU industry, we integrate them in the PACE ${ }^{5}$ modelling structure and develop the latter to conduct the analysis.

We find that using an electricity levy to reduce RE leads to a $0.2 \%$ GDP loss for the economy due to the associated distortion in comparison with public support for RE. Moreover, we observe that if an electricity levy is used, recycling auction revenues to support renewable energy generally benefits the EU economy more than if these revenues were transferred to households as lump-sum rebates (GDP loss of $0.1 \%$ instead of $0.2 \%$ ). This is because the auction revenues allow to reduce the electricity levy and the associated distortion. The impact on each economic sector is a combination of three effects: the positive effect of the reduction in the electricity levy for the industrial electricity consumers, the negative effect of an increased carbon price for the sectors covered by the carbon market, and a positive demand effect related to the increase in the economic activity. The final outcome is small but positive for the most electricity intensive non-ETS sectors,

\footnotetext{
${ }^{3}$ For recent information on how Member States support renewable electricity, we refer the reader to the RES LEGAL website: www.res-legal.eu.

${ }^{4}$ Our analysis focuses on the short-run impacts.

${ }^{5}$ Policy Analysis based on Computable Equilibrium
} 
or for those, such as the transport sector, that benefit from the increased demand from the whole economy. It is balanced for the other non-ETS sectors. For the ETS sectors, the benefit is clear if they are not exempted from the electricity levy, but if they are, their benefit from this exemption is reduced when recycling carbon auctions are used to support RE due to the increase in energy and carbon prices (1.6\% higher ETS price) induced by the electricity demand rise $(-2.2 \%)$ in the rest of the economy.

Section 2 presents the quantitative framework developed and used for the analysis. Section 3 describes the policy simulations considered. Section 4 discusses the results and Section 5 concludes.

\section{QUANTITATIVE FRAMEWORK}

This section covers the numerical general equilibrium framework employed for the analysis. We first present the data sources used. We explain the work conducted on them to obtain the level of sectoral detail needed for the analysis while ensuring consistency of the whole numerical framework. We then describe the modelling structure and the specific features developed to pursue the analysis.

\subsection{Data}

To analyse the interaction effects between auction revenues recycling and electricity levy exemption rules for energy-intensive sectors, we need detailed inputs for these industrials sectors. To do so, we use data from the GTAP 9.1 database (Global Trade Analysis Project), which we disaggregate and complement with inputs from the EU 2016 Reference Scenario (EC, 2016). The GTAP 9.1 database (Global Trade Analysis Project) provides the most recent consistent accounts of production, consumption, and bilateral trade flows for the reference year 2011. But, despite a rather comprehensive regional and sectoral coverage, this database does not provide sufficient sectoral detail about the energy-intensive industries. We hence apply disaggregation procedures to several energy-intensive sectors covered by the EU Emissions Trading Scheme (EU ETS). ${ }^{6}$ We use SplitCom routines (Horridge, 2008) to perform the sectoral disaggregation and refer the readers to Alexeeva-Talebi et al. (2012) for procedural information on this issue. ${ }^{7}$ Also, as the representation of the other sectors and regions in GTAP 9.1 is too specific for the purpose of this paper, we aggregate them. The model used for this sector covers 23 regions and 36 sectors (extractives activities, industries covered by the EU ETS, industries not covered by the EU ETS, services). EU regions include France, Germany, Italy, Poland, Spain, the United Kingdom, the

\footnotetext{
${ }^{6}$ The following GTAP sectors have been disaggregated: Chemical products, rubber and plastics (into organic chemicals, inorganic chemicals, fertilisers, other chemicals, rubber, plastics); Non-metallic minerals (into cement, glass, ceramics, bricks and tiles, other non-metallic minerals); Iron and steel (into basic production and further processing of iron and steel); Non-ferrous metals (into aluminium and other non-ferrous metals).

${ }^{7}$ The principle of the disaggregation routine is to find shares of production, consumption, trade and the intermediate production structure of the subsector within the aggregate sector. SplitCom then uses these shares to compute respective flows for the new subsectors and balances the input-output structure.
} 
other western Member States and the other Eastern Member States (the detailed regional coverage is reported in the appendix). The sectoral coverage is presented in Table 1.

For the base year, we derive $\mathrm{CO}_{2}$ emissions from fossil fuel inputs for the EU regions from the EU 2016 Reference Scenario. We decompose these figures using sectoral shares derived from the GTAP database. We add emissions from industrial processes. To do so, we use the World Input Output Database (WIOD, 2012), which includes emission figures with a very detailed breakdown of emission sources, i.e. 20 fossil energy carriers, relevant renewable energy sources and other sources. For each region and sector, we can derive process emissions from the data on "Emissions from other sources". 8

For the economic development up to 2030, we use data from both the EU 2016 Reference Scenario and the International Energy Outlook from the US Department of Energy (IEO, 2013). ${ }^{9}$ The former is used to calibrate most variables related to the EU regions of the model: energy inputs, prices of energy carriers, economic growth, and carbon prices. We complement these with data from the IEO 2013 for the non-EU regions.

Table 1: Sectoral coverage of the model

\begin{tabular}{|l|l|}
\hline Main aggregates & Sectors \\
\hline Extractive activities & Agriculture, forestry and fishing \\
\hline & Coal production \\
\hline & Crude oil extraction \\
\hline & Natural gas extraction \\
\hline Industries covered by the EU ETS & Mining, n.e.c. \\
\hline & Pulp and paper \\
\hline & Refineries and coke oven production \\
\hline & Fertilizer production \\
\hline & Organic chemical production \\
\hline & Inorganic chemical production \\
\hline & Cement production \\
\hline & Bricks and tiles production \\
\hline & Glass production \\
\hline & Ceramics production \\
\hline & Basic iron and steel production \\
\hline & Further processing of iron and steel \\
\hline & Aluminium production \\
\hline & \\
\hline
\end{tabular}

8 "Emission from other sources" in WIOD do, however, not include land use emissions.

${ }^{9}$ The IEO 2013 provides detailed regional data on total and fuel-specific primary energy consumption and carbon emissions given assumptions on the development of GDP, fossil fuel prices and other factors. The data take population growth and exogenous technical progress into account. 


\begin{tabular}{|l|l|}
\hline Main aggregates & Sectors \\
\hline & Production of other non-ferrous metals \\
\hline & Air transport \\
\hline Industries not covered by the EU ETS & Electricity \\
\hline & $\begin{array}{l}\text { Food production } \\
\text { leather }\end{array}$ \\
\hline & Manufacture of wood and wood products \\
\hline & Other chemicals, rubber, plastics production \\
\hline & Production of other non-metallic minerals \\
\hline & Manufacture of electrical and electronic \\
equipment
\end{tabular}

\subsection{General equilibrium model}

The analysis employs the PACE model, a multi-region, multi-sector recursive-dynamic computable general equilibrium (CGE) model of global trade and energy use. Each region in the model includes one representative agent which provides capital, labour and resources to the production sectors. The most important model features are briefly summarized below.

Production. Each region includes one representative firm per production sector, which is owned by the representative agent. Firms use primary factors provided by the representative agents and intermediate inputs to produce output. The production structure in each sector is specified using nested constant elasticity of substitution (CES) functions. We assume constant returns to scale for all sectors. In contrast to the top-down approach which underlies the other sectors of the model, the electricity sector is modelled as a bottom-up module for the EU regions. It differentiates the following energy carriers: coal, natural gas, oil, nuclear energy and renewable energy sources. By using technology-specific capital inputs based on exogenous data, electricity outputs for each energy source are computed. As in the other sectors, the production structure is based on nested constant elasticity of substitution functions. The resulting price of electricity is then included as an 
input price for the other model sectors. Capital in the electricity and resource extraction sectors are assumed to be sector-specific. We assume full mobility of capital and labour between the other sectors within each region. Firms maximize profits in perfectly competitive markets subject to their technology constraints.

Consumption. The consumer chooses a bundle of consumption goods that maximizes her utility given her preferences and budget. The budget is determined by the income received from selling the primary production factors (labour, capital and fossil fuels) that she owns and from government transfers. Moreover, she partly receives income from the revenues generated by auctioning emission permits. The extent of this income is, however, dependent on the policy scenarios described in section 3.2. Final demand of the representative consumer is modelled as a constant elasticity of substitution composite.

Equilibrium conditions. Zero-profit and market clearing conditions follow directly from the assumptions of profit maximization of firms, perfect competition among them, utility maximization of consumers, constant returns to scale in production, and homothety of consumer preferences. The latter class of conditions determines the most important endogenous variables of the model, i.e. the price of each output good as the unit cost to produce this good. Other endogenous variables include sectoral production levels, emissions, carbon prices and the deployment levels of the primary production factors.

Government. The government collects tax and tariff revenues and uses them for public spending. Government deficit and surplus are passed on to consumers as lump-sum transfers.

Trade. International trade is specified following the Armington approach of product heterogeneity (Armington, 1969). Domestic and imported goods for final consumption and for their use as intermediate products are distinguished by origin. ${ }^{10}$ Domestic and imported varieties form a CES composite which determines total supply of each good within the regions.

Böhringer et al. (2009) provide a diagrammatic structure and explain the underlying assumptions about the substitution possibilities in the production process of fossil and non-fossil goods, consumer preferences, $\mathrm{CO}_{2}$ accounting and the representation of trade links in the model. For the sake of compactness, we point the readers to this publication for more details. An updated algebraic description of the model and the corresponding nesting structures are presented in the appendix.

\footnotetext{
${ }^{10}$ Elasticities in international trade are based on empirical estimates reported in the GTAP 9.1 database.
} 


\subsection{Model development}

Three developments were included in the model: (i) the introduction of an electricity levy instrument to support RE with revenues from an electricity consumption tax, (ii) the introduction of the possibility for nations to exempt some of their economic sectors from this levy, and (iii) the introduction of the possibility for national governments to use carbon auction revenues to subsidize power generation from RE.

In the original version of the model, countries reach their renewable energy objectives in the power sector thanks to public support (paid by tax payers). We developed an electricity levy instrument by introducing an endogenous tax on electricity consumption in order for the associated revenues to cover the support needed by each country to reach a specific RE target share in electricity production. We introduced the possibility for countries to exempt some sectors from this levy.

In the model, auction revenues are by default transferred to households as lump-sum rebates. For the analysis, we introduced the possibility for national governments to transfer these revenues to the electricity sector as a subsidy for production from renewable energy. When carbon auction revenues are used to support electricity generation from renewable energy, the public support or electricity levy needed to reach the RE target is hence reduced.

\section{DESIGN OF POLICY SIMULATIONS}

This section explains how the EU climate and energy policy features required for the analysis are simulated and describes the scenarios considered.

\subsection{The EU climate policy and its simulation}

We present how the EU emissions objective is simulated in the analysis, both in the sectors covered by the EU ETS and in the other sectors via the effort sharing regulation. We explain how we model the EU ETS characteristics, in particular auctioning. We finally describe how we simulate the renewable energy policies at the EU and Member States level.

The 2030 climate and energy policy framework (EC, 2014a) includes the EU objective of a $40 \%$ reduction in GHG emissions ${ }^{11}$ compared to 1990 levels by 2030 . This target is further split into goals for the ETS and non-ETS sectors based on cost minimization principles (EC, 2014b). By 2030, the sectors covered by the EU ETS have to reduce their GHG emissions by $43 \%$ compared to 2005 levels whereas the sectors not covered by the EU ETS must decrease their emissions by 30\% compared to 2005 levels (EU, 2018b). For the non-ETS sectors (e.g. transport, buildings, agriculture and waste), binding annual greenhouse gas emission targets for Member States are established under the Effort Sharing Directive (ESD) for the period 2013-2020 (EU, 2009) and the Effort Sharing Regulation for the period 2021-2030 (EU, 2018a). Member States

\footnotetext{
${ }^{11}$ Energy and non-energy related emissions.
} 
are free to choose and design the policy instruments they want to employ to reach their respective objectives.

In the modelling exercise, full trade of allowances ${ }^{12}$ between ETS sectors of all EU Member States is simulated such that the cost efficient allocation of permits is eventually achieved. For the other sectors, given the fact that the ESD is driven by an attempt to equalize costs across Member States, we do not fully represent each Member State's target in the simulation, but we introduce carbon trading between these sectors. In the results section, we hence report the carbon constraint in the non-ETS sectors as a non-ETS carbon price. The $2.2 \%$ linear reduction factor for the EU ETS cap is imposed for the time period 2021-2030. In sectors that are on the carbon leakage list, ${ }^{13}$ carbon allowances are freely allocated up to sector specific benchmarks. ${ }^{14}$ In line with the EU ETS and auctioning regulations, full auctioning ${ }^{15}$ is used for the electricity sector, and, for the remaining sectors, 30\% of allowances are freely allocated up to sector-specific benchmarks in 2020 (this share is to be reduced to $0 \%$ by 2027 , i.e. 2030 in the simulation). A $1 \%$ flat rate is applied to the benchmark of the sectors on the carbon leakage list. ${ }^{16}$

In aggregate, for the time period 2021-2030, at least 57\% of emissions permits are auctioned and the rest is freely allocated. ${ }^{17}$

Regarding renewable energy, the 2030 climate and energy framework defined an overall EU objective of $27 \%$ share of renewable energy sources in gross final energy consumption by $2030 .^{18}$ In our simulations, this target is reflected at the Member State level by an increase in the share of

\footnotetext{
${ }^{12}$ In this study, we assume that the respective targets apply to $\mathrm{CO}_{2}$ emissions.

13 This list includes the following sectors: Refined oil and coal products/ Crude oil extraction/ Cement/ Bricks, tiles and construction products/ Glass/ Ceramics/ Manufacturing of iron and steel/ Aluminium/ Fertilizers and other nitrogen compounds/ Organic chemicals/ Inorganic chemicals/ Paper, pulp and printing products. This list mirrors the carbon leakage list of the European Commission (2014/746/EU, Annex, Commission Decision of 27 October 2014 ) to the extent possible, given the sectoral coverage of the model in comparison to the very detailed (NACE 4 classification) original list.

${ }^{14}$ We model free allocation as an output subsidy allocated to the firms, i.e. firms in a first step buy all of their emission permits and are then given back the value of a specific share of these permits, i.e. the benchmarked emissions.

${ }^{15}$ In our simulations, we do not take into account the fact that eight new Member States make use of derogation under Article 10c of the EU ETS directive, which allows them to issue a decreasing number of free allowances in the electricity sector. Some of these MS will even make use of this option beyond 2020 (http://ec.europa.eu/clima/policies/ets/cap/auctioning/in-dex_en.htm).

16 This means that, in 2025 and 2030, these sectors respectively receive only $85 \%$ and $80 \%$ of the respective benchmark allowances (based on 2007/2008 data) for free.

${ }^{17}$ Regarding the structural surplus of allowances, which has accumulated since 2014 and is included in the Market Stability Reserve (MSR) that starts in 2019, we assume that the additional allowances from the MSR will not be used before 2030 .

${ }^{18}$ In June 2018, the European Commission, Parliament and Council reached a political agreement that sets the renewable energy target to $32 \%$ by 2030, with an upwards revision clause by 2023.
} 
renewable energy in the electricity sector in line with the potential contribution of the electricity sector to the overall RE target, i.e. a 45\% share of RE in power generation. Even though the EU legislation does not set any RE target at Member State level, our modelling framework does require setting national targets, translated in shares of RE in power generation. ${ }^{19}$ These shares are based on the EUCO30 scenario of the European Commission (E3MLab and IIASA, 2016) and presented in Table 2. The targets for the aggregate regions (other Western MS, other Eastern MS) were computed as the weighted average taking into account national electricity demand.

Table 2: Assumed renewable energy share in power generation in 2030 based on EUCO30 scenario (in percent of the total power production)

\begin{tabular}{|l|c|}
\hline Model region & $\begin{array}{c}\text { Share of RE } \\
\text { in power } \\
\text { generation } \\
\text { (\%) }\end{array}$ \\
\hline France & 37.2 \\
\hline Germany & 45.6 \\
\hline Italy & 51.9 \\
\hline Poland & 26.5 \\
\hline Spain & 68.8 \\
\hline United Kingdom & 49.9 \\
\hline Rest of Western MS & 62.1 \\
\hline Rest of Eastern MS & 36.3 \\
\hline
\end{tabular}

\subsection{Scenarios}

Six scenarios are considered. They correspond to the combinations of three possible policy features and are presented in Table 3. First, EU Member States are free to set the type of renewable energy support policy they want. ${ }^{20}$ Most of them, except the United Kingdom, Poland and Finland, finance these support schemes by an electricity levy (paid by electricity consumers). Second, in the countries where an electricity levy applies, some sectors, e.g. energy intensive industries, may be exempted. For this reason, we first consider three scenarios: PUBLIC, in which RE support is publicly funded; LEVY, in which RE support is financed by an electricity levy paid by all electricity consumers; and LEVY_ETS_EXEMPT, in which RE support is financed by an electricity levy paid by all electricity consumers except the ETS sectors. Third, Member States are free to choose how to use the ETS auction revenues. Two ways are considered. One is to transfer

\footnotetext{
${ }^{19}$ This split is purely indicative: Member States will have the possibility to propose national contributions towards the EU RES target in their forthcoming national energy and climate plans.

${ }^{20}$ The renewable energy support policies used by European countries are reported in detail on the RES LEGAL website: http://www.res-legal.eu/.
} 
revenues to households as a lump sum. That is the option considered for the PUBLIC, LEVY and LEVY_ETS_EXEMPT scenarios. The alternative option studied here is to use these revenues to support power generation from RE. This option is applied in the corresponding PUBLIC_REN, LEVY_REN and LEVY_ETS_EXEMPT_REN scenarios. ${ }^{21,22}$

Table 3: Summary of policy scenarios

\begin{tabular}{|l|c|c|c|}
\cline { 2 - 4 } \multicolumn{1}{c|}{} & Public budget & $\begin{array}{c}\text { Electricity levy paid } \\
\text { by all consumers }\end{array}$ & $\begin{array}{l}\text { Electricity levy paid by all } \\
\text { consumers except ETS } \\
\text { sectors }\end{array}$ \\
\hline $\begin{array}{l}\text { Auction revenues } \\
\text { are transferred to } \\
\text { households }\end{array}$ & PUBLIC & LEVY & LEVY_ETS_EXEMPT \\
\hline $\begin{array}{l}\text { Auction revenues } \\
\text { are used to } \\
\text { subsidize power } \\
\text { production from } \\
\text { RE }\end{array}$ & PUBLIC_REN & LEVY_REN & LEVY_ETS_EXEMPT_REN \\
\hline
\end{tabular}

In the next section, the results are presented as percentage changes relative to the PUBLIC scenario.

\section{RESULTS AND DISCUSSION}

In this section, we first quantify the economic effects of using an electricity levy to fund RE support in comparison to using public money. This helps to understand the general equilibrium effects that are connected with recycling auction revenues to support renewable energy, and which we examine afterwards.

\subsection{Electricity levy versus public support for $\mathbf{R E}$}

If RE support is funded via an electricity levy, the aggregate energy demand as well as the electricity demand is reduced due to a price effect: as electricity consumers have to pay this levy

${ }^{21}$ In these three scenarios, support to RE paid by tax payers or electricity consumers is reduced in the proportion of the auction revenues used for that purpose.

${ }^{22}$ In France and Germany, the total amount of auction revenues is higher than the aggregate support needed to reach the renewable energy target. Therefore, we consider that only $60 \%$ and $80 \%$ of the carbon revenues in Germany and France, respectively, are recycled for RES support. 
in addition to the electricity price, ${ }^{23}$ they tend to reduce their electricity consumption. This distortionary tax induces a loss in GDP. This result is well known in the literature. In this section, we quantify these effects in order to better understand what happens when auction revenues are used to support RE in section 4.2. Table 4 reports the aggregate electricity and fossil fuel demand, the carbon price and non-ETS carbon constraint as well as GDP for all scenarios for the EU28 in 2030, in comparison to the PUBLIC scenario.

In the scenarios with a levy, the electricity demand is -2.2 to $-4.5 \%$ lower than in the PUBLIC scenario; the fossil demand is -0.2 to $-0.4 \%$ lower. This induces a lower ETS carbon price $(-2.2 \%$ to $-4.1 \%$ lower), which is directly associated with the reduction in electricity demand, and a higher non-ETS carbon constraint (between $6.3 \%$ and $14.6 \%$ higher), caused by the substitution of electricity by fossil energies in the production sectors. We observe a small GDP loss (-0.1 and $0.2 \%$ ) when RE support is funded via an electricity levy. The reason is that the electricity levy applies to a smaller tax base and implies more distortion than funding RE support via the general public budget. This economic activity loss is particularly true for the electricity consumers (households and industries) that have to pay the levy. This is illustrated in Figure 1, Figure 2 and Figure 3, which are analysed in more detail in section 4.2.

We note that if an electricity levy is employed, exempting the ETS sectors induces higher aggregate energy and electricity demands: for example, in the LEVY_ETS_EXEMPT scenario, the electricity demand is $4.1 \%$ lower than in the PUBLIC scenario, while it is $4.5 \%$ lower in the LEVY scenario. This is understandable as the absence of a levy for the ETS sectors leaves them better off and encourages them to use more electricity than if they had to pay this contribution. This may induce a very slight rise in the ETS carbon price: $0.13 \%$ in the LEVY_ETS_EXEMPT scenario compared to the LEVY scenario.

\subsection{Using carbon auction revenues to support RE}

The impact of recycling carbon auction revenues to subsidize renewable energy depends on how this support is financed. If the funding for the latter comes from the general public budget, this recycling option has no impact in our simulation. The reason is that, in our exercise, we assume that the government deficit and surplus are passed on to consumers as lump-sum transfers. While in the PUBLIC scenario households receive the carbon auction revenues as lump-sum transfers, in the PUBLIC_REN scenario, carbon auction revenues are not directly given to households: they are used to support RE, but the induced surplus for the government is reallocated to households, which then see the transfers they receive unchanged. We report this scenario as an element of comparison.

If RE support is funded via an electricity levy, we expect three mechanisms to take place. First, households do not receive the auction revenues as a lump-sum transfer any more. This should result in a reduction of their aggregate consumption (negative income effect). Second, when auction revenues are directly used to support electricity generation from renewable energy, the

\footnotetext{
${ }^{23}$ In this analysis, the electricity price does not include the electricity levy.
} 
electricity levy, which households and industries have to pay for their electricity consumption to support power generation from RE, is reduced. This results in a positive income effect and a reduction of the distortionary effects of the levy. For households, this should partly balance the negative income effect mentioned previously. Third, we expect the reduction in the electricity levy to induce a rise in the electricity consumption by industries and households (price effect).

We indeed observe a rise in electricity demand in the whole economy, as can be seen in Table 4. The electricity demand is $2.4 \%$ lower in LEVY_REN compared to the PUBLIC scenario while it is $4.5 \%$ lower in LEVY (corresponding to a $2 \%$ increase). Similarly, the electricity demand is reduced by $2.2 \%$ in LEVY_ETS_EXEMPT_REN and by $4.1 \% \%$ in LEVY_ETS_EXEMPT. This directly explains the higher ETS price in the scenarios with the renewable energy subsidy: a $1.6 \%$ increase in LEVY_REN compared to LEVY, a 1.8\% increase in LEVY_ETS_EXEMPT_REN compared to LEVY_ETS_EXEMPT. This ETS price increase is consistent with the finding of Nordhaus (1993) that the optimal carbon tax is higher if the associated revenues are used to reduce distortionary taxes than if they are lump-sum transferred to households. Our result extends this finding to the case of an ETS.

Table 4: Carbon price, fossil fuel demand and GDP for the EU28 aggregate in 2030

\begin{tabular}{|c|c|c|c|c|c|}
\hline Indicators & 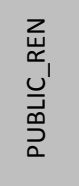 & 蚛 & $\begin{array}{l}z_{\underset{\sim}{*}} \\
z_{1} \\
\vec{u}\end{array}$ & 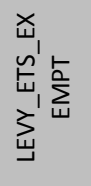 & 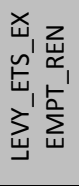 \\
\hline CO2 price ETS (2010 €) & 77.2 & 74.0 & 75.2 & 74.1 & 75.4 \\
\hline CO2 price non-ETS (2010 €) & 163.9 & 182.8 & 174.3 & 187.9 & 176.8 \\
\hline GDP (\% change vs. baseline) & 0.0 & -0.2 & -0.1 & -0.2 & -0.1 \\
\hline Fossil fuel demand (\% change vs. baseline) & 0.0 & -0.4 & -0.2 & -0.4 & -0.2 \\
\hline Electricity demand (\% change vs. baseline) & 0.0 & -4.5 & -2.4 & -4.1 & -2.2 \\
\hline Primary energy consumption (\% change vs. baseline) & 0.0 & -2.5 & -1.5 & -2.4 & -1.4 \\
\hline
\end{tabular}

The sectoral impacts of the recycling options are now presented. They are a combination of three effects: the reduction of the electricity levy is a benefit for the industrial electricity consumers, the increased carbon price induces a loss for the sectors covered by the carbon markets, and, for all sectors, the increased overall economic activity results in an increased demand. We differentiate below the non-ETS and the ETS sectors as the electricity levy exemption for the latter in some scenarios results in a change in the effect of the carbon revenues recycling option. ${ }^{24}$

\footnotetext{
${ }^{24}$ Detailed results for the output of all sectors are presented in Table 12 in Appendix 6.4.
} 


\section{2.a Non-ETS sectors}

For the non-ETS sectors, we expect at least two effects to take place. On the one hand, using

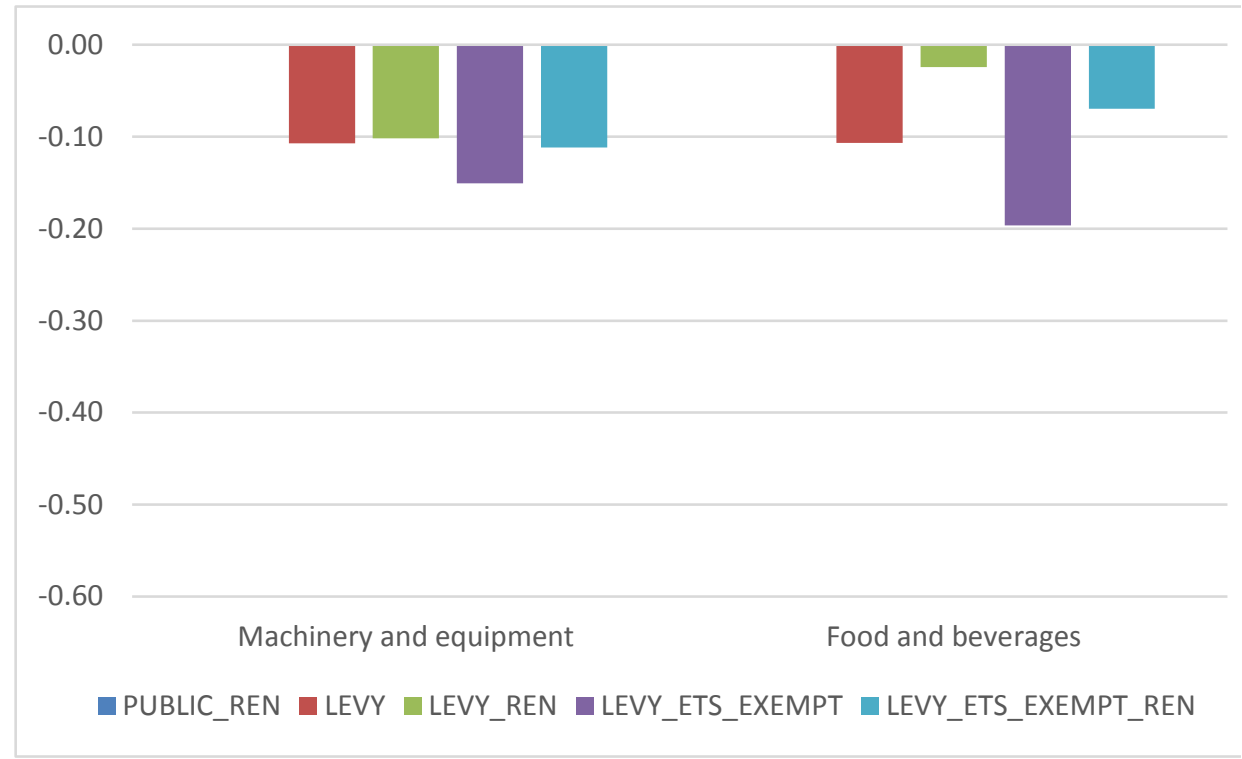

Figure 1: Change in output for two selected non-ETS sectors in 2030 (\% change compared to the PUBLIC scenario)

auction revenues to subsidize RE electricity generation should leave the non-ETS sectors better off because the electricity levy they have to pay is reduced. On the other hand, they can be disadvantaged by a possible increase in energy prices (a small electricity price increase due to a larger demand from the whole economy, and a subsequent small price increase for some fossil fuels). The final effect is a balance of the two and results in small variations. For the most electricity intensive of the non-ETS sectors the combined impact is positive. For example, the Food and beverage sector, which is relatively electricity-intensive compared to the other non-ETS sectors (cf. ranking of ETS and non-ETS sectors according to their electricity and energy intensities in appendix), slightly benefits as shown in Figure 1 below: the change in sectoral output is respectively -0.11 and -0.20 in the LEVY and LEVY_ETS_EXEMPT scenarios in comparison to PUBLIC, while it is only -0.02 and -0.07 in LEVY_REN and LEVY_ETS_EXEMPT REN. For other non-ETS sectors, the effects mentioned above balance one another and the final impact is minor. As an example, for the manufacturing sectors (e.g. Machinery and Equipment), the sectoral output changes compared to the PUBLIC scenario are between -0.10 and $-0.15 \%$ for all scenarios. 
Some sectors such as Inland Transport sector benefit from this recycling option (cf. Figure 2) due to a demand effect from the non-ETS sectors that have to pay the electricity levy and are better off when the latter is reduced: for example, the sectoral output of this sector is reduced by $0.58 \%$ in the LEVY_ETS_EXEMPT scenario relative to the PUBLIC scenario, but by $0.30 \%$ in the LEVY_ETS_EXEMPT_REN case.

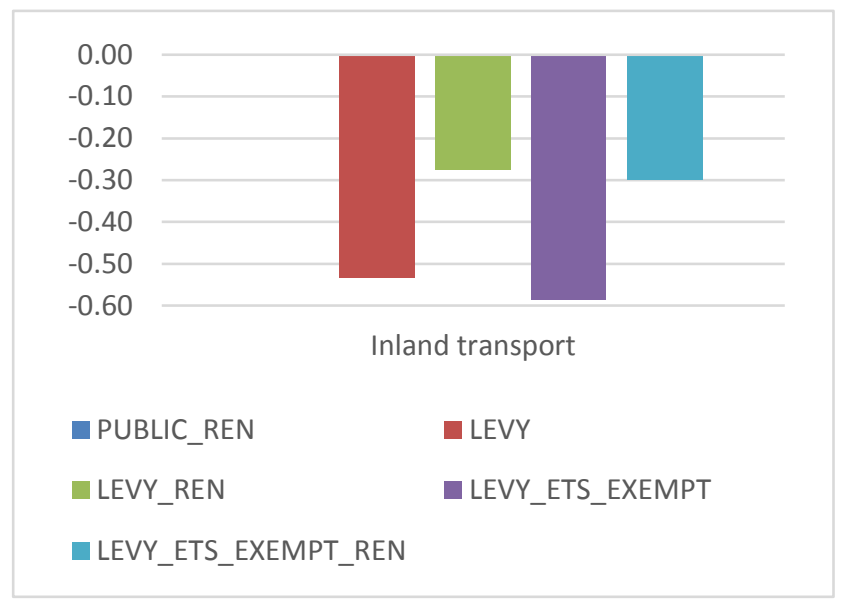

In aggregate, despite the fact that the activity of some non-ETS sectors is higher when auction

Figure 2: Change in output for Inland transport in 2030 (\% change compared to the PUBLIC scenario)

revenues are used to support renewable electricity, the non-ETS carbon price is smaller (a 5.9\% reduction in LEVY_ETS_EXEMPT_REN compared to LEVY_ETS_EXEMPT). The reason is that the reduced electricity levy allows these sectors to make use of cheaper abatement opportunities, in particular, through a larger use of electricity (a 3.3\% change in electricity demand from all non-ETS sectors in LEVY_ETS_EXEMPT_REN compared to LEVY_ETS_EXEMPT).

\section{2.b ETS sectors}

The impact of using carbon revenues to support RE on the output of the ETS sectors is still a combination of the three effects described above (reduced electricity levy, increased carbon and energy prices, increased economic activity) and depends on the potential electricity levy exemption for these sectors (see Figure 3 for three selected sectors). If they have to pay the electricity levy, the recycling of the auction revenues to support electricity production from RE results in a reduction of the levy. This positive income effect leaves the ETS sectors better off: $-1.35 \%$ in aluminium sector output in LEVY_REN compared to the PUBLIC scenario in contrast with - $2.3 \%$ in LEVY; $-0.52 \%$ in the sector of iron and steel manufacturing in LEVY_ REN compared with $0.94 \%$ in LEVY. In aggregate, the ETS sectors use 3.4\% more electricity than if auction revenues are transferred to households. The GDP is slightly higher when auction revenues are used to 
support RE: $-0.1 \%$ in the LEVY_REN scenario compared to PUBLIC, $-0.2 \%$ in the LEVY scenario. This is consistent with the finding of Ballard and Medema (1993), relative to the efficiency gain due to the reduction of other - distortionary - taxes that a Pigouvian tax allows. Our result extends this finding to the case of an ETS. As explained in section 4.1, employing an electricity levy induces a slight GDP loss due to its distortionary effects. These are reduced when the use of auction revenues to support RE allows a reduction in the levy.

If the ETS sectors are exempted from the levy, the difference in application of the latter to the various economic sectors induces general equilibrium effects. The increased electricity demand in the whole economy results in a higher ETS carbon price and a slight increase in the price of electricity in some countries (for example 3\% in France in the scenarios with the subsidy compared to the scenarios without). This has a negative impact on the ETS sectors. In parallel, however, the demand from the non-ETS sectors increases. As a consequence, the final outcome for the ETS sectors is a balance of the two effects (see detailed sectoral results in appendix). Sectors such as Fertilizers, Organic chemicals and Inorganic chemicals still benefit from the recycling option, as the demand effect dominates for them. As an example, the output for Fertilizers is reduced by 0.5 $\%$ in LEVY_ETS_EXEMPT compared to PUBLIC, but only by $0.3 \%$ in LEVYETS_EXEMPT_REN. This is likely due to the demand by the agricultural sector (output reduced by $0.3 \%$ in LEVY_ETS_EXEMPT compared to PUBLIC, and by $0.1 \%$ in LEVY_ETS_EXEMPT_REN). On the contrary, the most electricity intensive ETS sectors are worse off as a consequence of the use of auction revenues to subsidize renewable electricity generation and the consequent increased energy and carbon prices: for the aluminium sector, the output rises by $0.5 \%$ in the LEVY_ETS_EXEMPT scenario relative to the PUBLIC scenario, compared with $0.1 \%$ in LEVY_ETS_EXEMPT_REN; for the sector of iron and steel manufacturing, the respective changes are $0.3 \%$ and $0.1 \%$.

In aggregate for the whole economy, the GDP is slightly better $(-0.1 \%$ change in LEVY_ETS_EXEMPT_REN relative to PUBLIC, compared with $-0.2 \%$ in LEVY_ETS_EXEMPT). This is explained by the increased output in some non-ETS sectors. These sectors are not exempted from the levy but they have a significant use of electricity and benefit when auction revenues are used to support RE electricity. We explain the improvement in terms of GDP by the reduction of the electricity levy and the associated distortionary effect. 
Except for electricity, which is obviously better off when benefiting from a subsidy, the impacts of this auction revenues recycling option on the output of the ETS as well as non-ETS sectors does

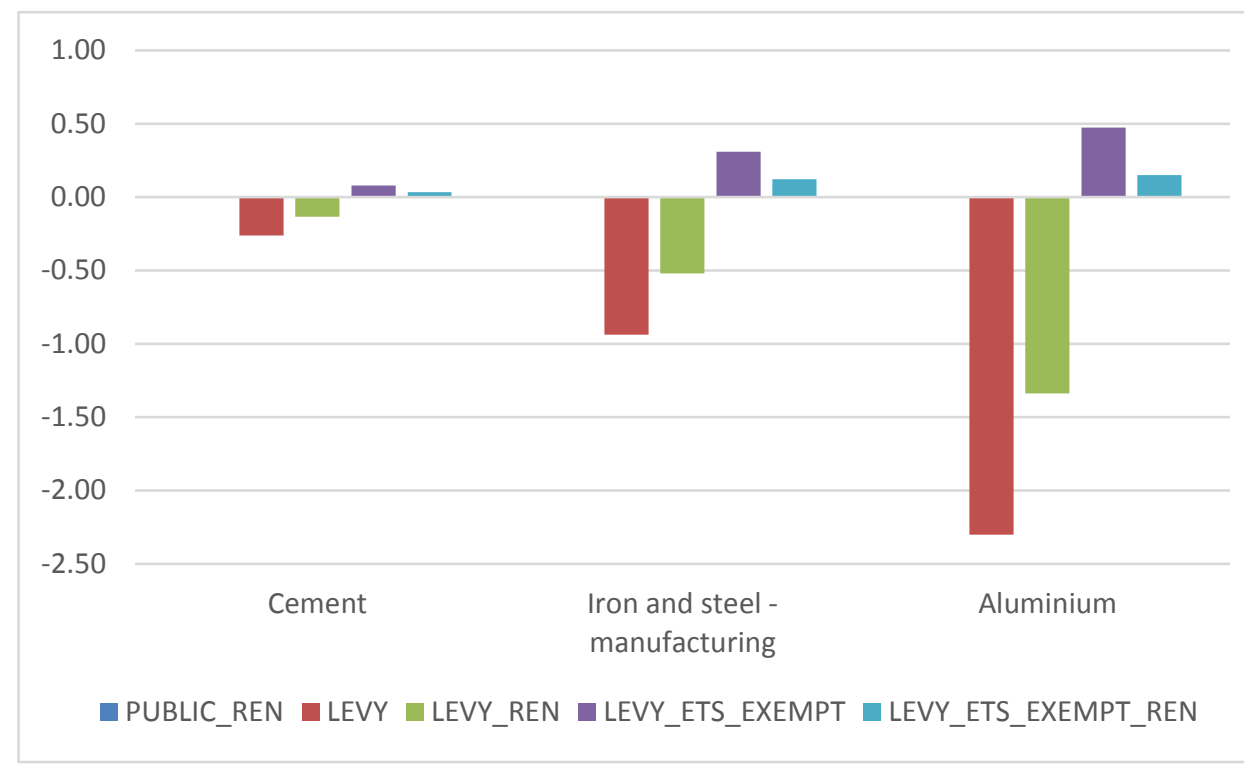

Figure 3: Changes in output of selected sectors in 2030 (\% change compared to the PUBLIC scenario)

not result in significant changes in their world market shares. We explain this by pointing to the fact that the sectoral changes are relatively small. This is an interesting result in the policy context of the Energy Union Package (EC, 2015), in which industrial competitiveness concerns are taken into consideration.

Besides the analysis of the sectoral impacts on ETS and non-ETS sectors, we observe that, in our simulation, the effect of this carbon revenues recycling method on households is negligible. The reason is that households do not receive the auction revenues as a lump-sum any more but they benefit from the increased economic activity. In order to fully inform policy-makers about the social impacts of such a scheme, the analysis could be complemented by a microsimulation approach comparable to the one conducted by Böhringer et al. (2017).

Regarding the environmental impacts of such a scheme, we note that the auctions recycling method does not change the cap of the EU ETS, nor the mitigation objectives in the non-ETS sectors. On an environmental level, it may only have an impact on co-pollutants via the sectoral output changes described above.

\section{CONCLUSIONS}

As ETS's are being developed by an increasing number of nations as instruments in order to reduce greenhouse gas emissions, behavioural studies have shown that the political and public 
acceptability of these instrument depends on the use of the associated revenues. An option the general public approves of is to employ revenues to support renewable energy development.

This analysis aims at examining the economic impact of such a recycling option as a function of the type of RE policy funding and potentially associated sectoral exemption rules. It extends the literature on environmental taxation in the presence of other taxes to carbon pricing in the form of an emissions trading scheme, in the presence of a distortionary commodity tax - the electricity levy - that heterogeneously applies to the various sectors of the economy.

The study is conducted on the EU case and takes account of the EU objectives regarding emissions reductions and renewable energy as stated in the 2030 climate and energy framework. The methodology employed uses detailed sectoral data on ETS and non-ETS sectors, data which are gathered and combined to develop the PACE model. The scenarios analysed include public support for RE, the use of an electricity levy with or without exemptions for the energy intensive sectors, and the associated scenarios in which carbon auction revenues are recycled to support RE instead of being transferred to households.

In our analysis, public support for renewable energy results in better outcomes for the whole economy than an electricity levy (-0.2\% GDP loss with levy) due to the distortion the latter induces and the cost it implies for electricity consumers (households and industries). Only ETS sectors benefit if they are exempted from this levy.

If auction revenues are used to support RE and reduce the levy, the distortionary effect is diminished and there is a relative GDP improvement (-0.1\% GDP loss instead of $0.2 \%)$. The ETS price rises $(+1.6 \%$ if no levy exemption applies, $+1.8 \%$ if ETS sectors are exempted) as a result of the higher electricity demand, but a reduction of the climate constraint $(-4.6 \%$ if no levy exemption applies, $-5.9 \%$ if ETS sectors are exempted) is observed in the non-ETS sectors, which can use more electricity. The impact on each economic sector is a combination of three effect: a positive income effect associated with the electricity levy reduction for the industrial electricity consumers, a loss induced by higher energy and carbon prices for the most energy intensive sectors, an increased demand from the whole economy. For the non-ETS sectors, the outcome is either balanced or positive but, in all cases, small. The impact on the ETS sectors depends on the exemption rules. If they have to pay the electricity levy, the recycling of the auction revenues to support RE results in a positive income effect for them and leaves them better off. On the contrary, if the ETS sectors are exempted, the use of auction revenues to subsidize renewable electricity generation leaves the most energy intensive ones worse off. Despite an increase in the demand from the non-ETS sectors that have to pay the electricity levy and are better off when the latter is reduced (e.g. demand for fertilizers by the agricultural sector), some of the ETS sectors that benefit from a levy exemption see their benefit from the exemption reduced due to increased carbon and energy prices. That is for example the case of the cement, iron and steel, glass, and aluminium sectors.

The impacts of this auction revenues recycling option on the output of the ETS as well as nonETS sectors does not result in significant changes in their world market shares. We explain this by 
pointing to the fact that the sectoral changes remain relatively small. This is interesting in the EU context, where competitiveness is part of the objectives of the energy and climate policy.

The effect of shifting carbon revenues to support RE on households is negligible. Even if the latter do not directly receive the auction revenues any more, they benefit from the increased economic activity. To obtain a more detailed analysis of the social impacts of such a scheme, we would suggest using a microsimulation approach comparable to the one used by Böhringer et al. on Germany (2017).

With regard to the environmental effects, we remind that using the auction revenues to support RE does not alter the cap of the EU ETS, nor the emission reductions objectives in the non-ETS sectors. The only environmental impact it could have is on co-pollutants due to the output changes of industrial sectors.

Our study has interesting policy implications regarding renewable energy support, potentially associated exemption rules and interactions with carbon revenues recycling options. Such a recycling method has no significant impact if there is public support for $\mathrm{RE}$ and if government deficits and surpluses are passed on to households as lump-sum transfers. On the contrary, if an electricity levy is used to finance RE, the reduction of this levy, as a consequence of using carbon revenues to subsidize power generation from RE, induces a reduction of the distortionary effects of this levy and a GDP improvement.

\section{Acknowledgments}

This research has been financially supported by the European Agency for Small and MediumSized Enterprises (EASME) and the European Commission under the project "EU competitiveness and the 2030 framework - An industry perspective" (Contract EASME/COSME/2014/031). This work benefited from interactions with different services of the European Commission, including DG CLIMA, DG ECFIN, DG ENER, DG GROW, DG MOVE, and the Joint Research Centre. The authors thank Christoph Böhringer, Wolfgang Habla, Katheline Schubert, Ulrich Wagner, as well as conference and seminar participants for helpful comments received in response to presentations of this paper, in particular at the World Congress of Environmental and Resource Economists, the $5^{\text {th }}$ conference of the French Association of Environmental and Resource Economists, the $7^{\text {th }}$ Mannheim Energy Conference, the FSR Climate Annual Conference 2018, and internal ZEW lunch seminars. The ideas expressed here are those of the authors, who alone are responsible for errors and omissions. 


\section{APPENDIX}

\subsection{Algebraic model summary}

Table 5: Activity variables

\begin{tabular}{|cl|}
\hline Variable & Description \\
\hline$y_{i, r}$ & Aggregate production in sector $i$ and region $r$ \\
$y_{\text {tec }, r}^{\text {ele }}$ & Aggregate production in electricity sector of region \\
& $r$ and technology tec \\
$y_{x e, r}$ & Aggregate production of exhaustible resource $x e$ in \\
$y_{i, r}^{A}$ & region $r$ \\
$y_{i, r}^{M}$ & Armington aggregate in sector $i$ and region $r$ \\
$y_{r}^{W}$ & Import of sector $i$ in region $r$ \\
\hline
\end{tabular}

Table 6: Price variables

\begin{tabular}{|cl|}
\hline Variable & Description \\
\hline$p_{i, r}^{Y}$ & Price of aggregate output of sector $i$ in region $r$ \\
$p_{e l e, r}^{Y}$ & Price of aggregate output in electricity sector of \\
& region $r$ and technology tec \\
$p_{x e, r}^{Y}$ & Price of aggregate output of exhaustible resource $x e$ \\
$p_{j, i, r}^{A}$ & in region $r$ \\
$p_{i, r}^{M}$ & Price of Armington good in sector $i$ and region $r$ \\
$p_{i}^{T}$ & Price of import good in sector $i$ and region $r$ \\
$p_{r}^{W}$ & Price of transport good in sector $i$ \\
$v_{r}$ & Welfare price in region $r$ \\
$w_{r}$ & Return to capital in region $r$ \\
$q_{x e, r}$ & Wage rate in region $r$ \\
$p_{r}^{C O_{2}}$ & Rent to exhaustible resource $x e$ in region $r$ \\
&
\end{tabular}

Table 7: Additional variables

\begin{tabular}{|cl|}
\hline Variable & Description \\
\hline$R A_{r}$ & Income level of representative agent in region $r$ \\
$\mu_{r}$ & Subsidy on renewable energy \\
$\tau_{r}$ & Tax on electricity consumption in region $r$ \\
$\psi_{r}$ & Green quota in power production in region $r$ \\
\hline
\end{tabular}


Table 8: Cost shares

\begin{tabular}{|c|c|}
\hline Parameter & Description \\
\hline$\theta_{i, r}^{M a t}$ & $\begin{array}{l}\text { Benchmark cost share of materials in aggregate } \\
\text { output of sector } i \text { in region } r\end{array}$ \\
\hline$\theta_{i, r}^{E}$ & $\begin{array}{l}\text { Benchmark cost share of energy in capital-labor- } \\
\text { energy composite of sector } i \text { in region } r\end{array}$ \\
\hline$\theta_{i, r}^{K}$ & $\begin{array}{l}\text { Benchmark cost share of capital in value added } \\
\text { composite of sector } i \text { in region } r\end{array}$ \\
\hline$\theta_{i, r}^{\text {col }}$ & $\begin{array}{l}\text { Benchmark cost share of the coal- } \mathrm{CO}_{2} \text { permit } \\
\text { composite in energy composite of sector } i \text { in region } \\
r\end{array}$ \\
\hline$\theta_{i, r}^{\text {oil }}$ & $\begin{array}{l}\text { Benchmark cost share of the oil- } \mathrm{CO}_{2} \text { permit } \\
\text { composite in oil-gas composite of sector } i \text { in region } \\
r\end{array}$ \\
\hline$\theta_{r}^{\text {colem }}$ & $\begin{array}{l}\text { Benchmark cost share of coal in coal- }-\mathrm{CO}_{2} \text { permit } \\
\text { composite in region } r\end{array}$ \\
\hline$\theta_{r}^{\text {oilem }}$ & $\begin{array}{l}\text { Benchmark cost share of oil in oil- } \mathrm{CO}_{2} \text { permit } \\
\text { composite in region } r\end{array}$ \\
\hline$\theta_{r}^{\text {gasem }}$ & $\begin{array}{l}\text { Benchmark cost share of gas in gas- } \mathrm{CO}_{2} \text { permit } \\
\text { composite in region } r\end{array}$ \\
\hline$\theta_{t e c, r}^{K}$ & $\begin{array}{l}\text { Benchmark cost share of capital in electricity } \\
\text { generation for technology tec in region } r\end{array}$ \\
\hline$\theta_{\text {ele }, r}^{L M}$ & $\begin{array}{l}\text { Benchmark cost share of material-labor composite } \\
\text { in non-technology input of electricity sector in } \\
\text { region } r\end{array}$ \\
\hline$\theta_{\text {ele }, r}^{\text {MatL }}$ & $\begin{array}{l}\text { Benchmark cost share of material-labor composite of } \\
\text { electricity sector in region } r\end{array}$ \\
\hline$\theta_{x e, r}^{R}$ & $\begin{array}{l}\text { Benchmark cost share of exhaustible resource } x e \text { in } \\
\text { region } r\end{array}$ \\
\hline$\theta_{s, r}^{Y}$ & $\begin{array}{l}\text { Benchmark cost share of goods from region } s \text { in } \\
\text { Armington aggregate of region } r\end{array}$ \\
\hline$\theta_{s, r}^{M}$ & $\begin{array}{l}\text { Benchmark cost share of goods from region } s \text { in } \\
\text { aggregate import good of region } r\end{array}$ \\
\hline$\theta_{j, i, S}^{T}$ & $\begin{array}{l}\text { Benchmark cost share of transport good from } \\
\text { region } s \text { from sector } j \text { to sector } i\end{array}$ \\
\hline
\end{tabular}


Table 9: Endowments

\begin{tabular}{|c|c|}
\hline Parameter & Description \\
\hline$\overline{K_{r}}$ & Capital endowment in region $r$ \\
\hline$\overline{k_{l, r}}$ & $\begin{array}{l}\text { Benchmark capital demand in the value added nest } \\
\text { of sector } i \text { in region } r\end{array}$ \\
\hline$\overline{t k_{t e c, r}}$ & $\begin{array}{l}\text { Benchmark capital demand in electricity sector of } \\
\text { technology tec in region } r\end{array}$ \\
\hline$\overline{L_{r}}$ & Labor endowment in region $r$ \\
\hline$\overline{l_{l, r}}$ & $\begin{array}{l}\text { Benchmark labor demand in the value added nest of } \\
\text { sector } i \text { in region } r\end{array}$ \\
\hline$\overline{Q_{x e, r}}$ & Endowment of resource $x e$ in region $r$ \\
\hline$\overline{C_{l, r, s}}$ & Benchmark bilateral trade flows \\
\hline$\overline{\mathrm{CO}_{2 r}}$ & $\mathrm{CO}_{2}$ emissions target in region $r$ \\
\hline$\overline{r e n_{r}}$ & Renewable target in region $r$ \\
\hline
\end{tabular}

Table 10: Elasticities

\begin{tabular}{|cl|}
\hline Parameter & Description \\
\hline$\sigma_{K L E M}$ & $\begin{array}{l}\text { Substitution between materials and the energy- } \\
\text { value added composite }\end{array}$ \\
& $\begin{array}{c}\text { Substitution between energy and the value added } \\
\sigma_{K L E}\end{array}$ \\
$\sigma_{K L}$ & Somposite \\
$\sigma_{N E L}$ & Substitution between capital and labor \\
$\sigma_{L Q D}$ & Substitution between coal and the oil-gas composite \\
& Substitution between oil and gas \\
$\sigma_{t e c}$ & $\begin{array}{l}\text { and the non-technology inputs composite in } \\
\text { electricity generation }\end{array}$ \\
& Substitution between resources and the materials- \\
$\sigma_{r e s}$ & value added composite in resource extraction \\
$\sigma^{A}$ & Armington elasticity \\
$\sigma^{M}$ & Substitution between imports by origin country \\
\hline
\end{tabular}




\section{Zero-profit conditions}

1. Sectoral output (except for electricity in the EU regions and for fossil fuel resources)

$$
\left(\theta_{i, r}^{\text {Mat }}\left(\sum_{j} p_{j, i, r}^{A}\left(1+\tau_{r}\right)\right)^{1-\sigma_{K L E M}}+\left(1-\theta_{i, r}^{M a t}\right)\left(k l e_{i, r}\right)^{1-\sigma_{K L E M}}\right)^{1 /\left(1-\sigma_{K L E M}\right)} \geq p_{i, r}^{Y}
$$

where

$$
\begin{gathered}
k l e_{i, r}=\left(\theta_{i, r}^{E}\left(e n_{i, r}\right)^{1-\sigma_{K L E}}+\left(1-\theta_{i, r}^{E}\right) v a_{i, r}^{1-\sigma_{K L E}}\right)^{1 /\left(1-\sigma_{K L E}\right)} \\
v a_{i, r}=\left(\theta_{i, r}^{K} v_{r}^{1-\sigma_{K L}}+\left(1-\theta_{i, r}^{K}\right) w_{r}^{1-\sigma_{K L}}\right)^{1 /\left(1-\sigma_{K L}\right)} \\
e n_{i, r}=\left(\theta_{i, r}^{c o l} \operatorname{col}_{i, r}^{1-\sigma_{N E L}}+\left(1-\theta_{i, r}^{\text {col }}\right) l q d_{i, r}^{1-\sigma_{N E L}}\right)^{1 /\left(1-\sigma_{N E L}\right)} \\
l q d_{i, r}=\left(\theta_{i, r}^{\text {oil oil }} l_{i, r}^{1-\sigma_{L Q D}}+\left(1-\theta_{i, r}^{\text {oil }}\right) g a s_{i, r}^{1-\sigma_{L Q D}}\right)^{1 /\left(1-\sigma_{L Q D}\right)} \\
\operatorname{col}_{i, r}=\max \left\{\theta_{r}^{\text {colem }} p_{c o l, r}^{Y} ;\left(1-\theta_{r}^{\text {colem }}\right) p_{r}^{C O_{2}}\right\} \\
\text { oil }_{i, r}=\max \left\{\theta_{r}^{\text {oilem }} p_{\text {oil }, r}^{Y} ;\left(1-\theta_{r}^{\text {oilem }}\right) p_{r}^{C O_{2}}\right\}
\end{gathered}
$$

and

$$
\operatorname{gas}_{i, r}=\max \left\{\theta_{r}^{\text {gasem }} p_{g a s, r}^{Y} ;\left(1-\theta_{r}^{\text {gasem }}\right) p_{r}^{C O_{2}}\right\}
$$

2. Electricity (only in the EU regions $-\psi_{r}$ only applies to tec $=$ ren)

$$
\begin{aligned}
& \left(\theta_{\text {tec }, r}^{K}\left(\sum_{\text {tec }} v_{\text {tec }, r}\right)^{1-\sigma_{t e c}}+\left(1-\theta_{\text {tec }, r}^{K}\right) i n p_{\text {ele }, r}^{1-\sigma_{\text {tec }}}\right)^{1 /\left(1-\sigma_{t e c}\right)} \geq p_{\text {ele }, r}^{Y}\left(1+\psi_{r}\right)\left(1+\mu_{r}\right) \\
& \perp y_{\text {tec }, r}^{\text {ele }}
\end{aligned}
$$

where

$$
i n p_{\text {ele }, r}=\max \left\{\theta_{\text {ele }, r}^{L M} l m_{e l e, r} ;\left(1-\theta_{\text {ele }, r}^{L M}\right) e n_{\text {ele }, r}\right\}
$$




$$
\begin{aligned}
& l m_{e l e, r}=\max \left\{\theta_{e l e, r}^{M a t L} \sum_{j \backslash f e} p_{j, e l e, r}^{A} ;\left(1-\theta_{e l e, r}^{M a t L}\right) w_{r}\right\} \\
& e n_{\text {ele }, r}=\max \left\{\theta_{\text {ele }, r}^{\text {col }} \operatorname{col}_{\text {ele }, r} ; \theta_{\text {ele }, r}^{\text {oil }} \text { oil } l_{\text {ele }, r} ; \theta_{\text {ele }, r}^{\text {gas }} \text { gas } s_{\text {ele }, r}\right\} \\
& \operatorname{col}_{i, r}=\max \left\{\theta_{r}^{\text {colem }} p_{\text {col, }, r}^{Y} ;\left(1-\theta_{r}^{\text {colem }}\right) p_{r}^{\mathrm{CO}_{2}}\right\} \\
& o i l_{i, r}=\max \left\{\theta_{r}^{\text {oilem }} p_{\text {oil }, r}^{Y} ;\left(1-\theta_{r}^{\text {oilem }}\right) p_{r}^{\mathrm{CO}_{2}}\right\}
\end{aligned}
$$

and

$$
\operatorname{gas}_{i, r}=\max \left\{\theta_{r}^{\text {gasem }} p_{g a s, r}^{Y} ;\left(1-\theta_{r}^{\text {gasem }}\right) p_{r}^{\text {CO }_{2}}\right\}
$$

\section{Resource extraction}

$$
\left(\theta_{x e, r}^{R} q_{x e, r}^{1-\sigma_{r e s}}+\left(1-\theta_{x e, r}^{R}\right) k l m_{x e, r}^{1-\sigma_{r e s}}\right)^{1 /\left(1-\sigma_{r e s}\right)} \geq p_{x e, r}^{Y} \perp y_{x e, r}
$$

where

$$
k l m_{x e, r}=\max \left\{\theta_{x e, r}^{M a t} \sum_{j} p_{j, r}^{Y} ; \theta_{x e, r}^{K} v_{r} ; \theta_{x e, r}^{L} w_{r}\right\}
$$

4. Armington aggregate

$$
\left(\sum_{s} \theta_{s, r}^{Y} p_{i, r}^{Y}{ }^{1-\sigma^{A}}\right)^{1 /\left(1-\sigma^{A}\right)} \geq p_{j, i, r}^{A} \perp y_{i, r}^{A}
$$

5. Imports

$$
\left(\sum_{s} \theta_{s, r}^{M} t y_{j, i, s}^{1-\sigma^{M}}\right)^{1 /\left(1-\sigma^{M}\right)} \geq p_{i, r}^{M} \perp y_{i, r}^{M}
$$

where

$$
t y_{j, i, s}=\max \left\{\theta_{j, i, s}^{T} p_{i, s}^{Y} ;\left(1-\theta_{j, i, s}^{T}\right) p_{j}^{T}\right\}
$$

6. Welfare

$$
\sum_{j} p_{j, r}^{Y} \geq p_{r}^{W} \perp y_{r}^{W}
$$




\section{Market-clearing conditions}

7. Sectoral output

$$
y_{i, r} \geq \sum_{s} \overline{c_{l, r, s}} y_{i, s}^{A}\left(\frac{p_{i, s}^{A}}{p_{i, r}^{Y}}\right)^{\sigma^{A}} \perp p_{i, r}^{Y}
$$

8. Capital

$$
\overline{K_{r}} \geq \sum_{t e c} \overline{t k_{t e c, r}} y_{e l e, r}\left(\frac{p_{e l e, r}^{Y}}{v_{t e c, r}}\right)^{\sigma_{t e c}}+\sum_{i} \overline{k_{l, r}} y_{i, r}\left(\frac{p_{i, r}^{Y}}{v_{r}^{\theta_{i, r}^{K}} w_{r}^{1-\theta_{i, r}^{K}}}\right)^{\sigma_{K L}} \frac{v_{r}^{\theta_{i, r}^{K}} w_{r}^{1-\theta_{i, r}^{K}}}{v_{r}} \perp v_{r}
$$

9. Labor

$$
\overline{L_{r}} \geq \sum_{i} \overline{l_{l, r}} y_{i, r}\left(\frac{p_{i, r}^{Y}}{v_{r}^{\theta_{i, r}^{K}} w_{r}^{1-\theta_{i, r}^{K}}}\right)^{\sigma_{K L}} \frac{v_{r}^{\theta_{i, r}^{K}} w_{r}^{1-\theta_{i, r}^{K}}}{w_{r}} \perp w_{r}
$$

10. Armington

$$
\sum_{s} c_{i, s, r} y_{i, r}^{A} \geq \sum_{s} c_{i, s, r} y_{r}^{W} \frac{p_{r}^{W}}{p_{i, r}^{A}} \perp p_{i, r}^{A}
$$

11. Welfare

$$
y_{r}^{W} \sum_{i, s} c_{i, s, r} \geq \frac{R A_{r}}{p_{r}^{W}} \perp p_{r}^{W}
$$

12. Emissions (only for emissions regulating regions and for both the ETS and NETS market segments)

$$
\overline{\mathrm{CO}_{2 r}} \geq y_{c o l, r}+y_{o i l, r}+y_{g a s, r} \perp p_{r}^{C O_{2}}
$$

\section{Constraints}

13. Green quota in power production

$$
y_{r e n, r}^{e l e}=\overline{r e n_{r}} \sum_{t e c} y_{t e c, r}^{\text {ele }} \perp \psi_{r}
$$

14. Tax on electricity consumption (does not apply to sectors exempted from electricity levy) 


$$
\tau_{r} \sum_{i} p_{e l e, i, r}^{A} y_{i, r}=\alpha_{r} p_{e l e, r}^{Y} \psi_{r} y_{r e n, r}^{e l e} \perp \tau_{r}
$$

15. Subsidy on renewable energy (as a recycling option of permit auctioning revenues)

$$
\mu_{r} p_{e l e, r}^{Y} y_{r e n, r}^{e l e}=\beta_{r} p_{r}^{C O_{2}} \sum_{f e} b C_{f e, r} \perp \mu_{r}
$$

Income balance

16.

$$
\begin{aligned}
R A_{r}=\overline{K_{r}} v_{r}+ & \overline{L_{r}} w_{r}+\sum_{x e} \overline{Q_{x e, r}} q_{x e, r}+\sum_{t e c} \overline{t k_{t e c, r}} v_{t e c, r}+\overline{C O_{2 r}} p_{r}^{C O_{2}}-\mu_{r} p_{e l e, r}^{Y} y_{r e n, r}^{e l e} \\
& +\tau_{r} \sum_{i} p_{e l e, i, r}^{A} y_{i, r}-\psi_{r} p_{e l e, r}^{Y} y_{r e n, r}^{e l e} \perp R A_{r}
\end{aligned}
$$




\subsection{Regional coverage of the model}

Table 11: Regional coverage of the model

\begin{tabular}{|l|l|}
\hline Main aggregates & Countries or groups of countries \\
\hline EU regions & Germany (DEU) \\
\hline & France (FRA) \\
\hline & United Kingdom (GBR) \\
\hline & Spain (ESP) \\
\hline & Poland (POL) \\
\hline & Italy (ITA) \\
\hline & $\begin{array}{l}\text { Rest of Western Member States: Denmark, Sweden, Finland, } \\
\text { Greece, Malta, Cyprus (XWE) }\end{array}$ \\
\hline & $\begin{array}{l}\text { Rest of Eastern Member States: Czech Republic, Slovakia, } \\
\text { Hungary, Slovenia, Bulgaria, Romania, Croatia, Estonia, Latvia, } \\
\text { Lithuania (XEE) }\end{array}$ \\
\hline & United States of America (USA) \\
\hline Canada (CAN) \\
\hline & Japan (JPN) \\
\hline & Russia (RUS) \\
\hline & Australia (AUS) \\
\hline & Turkey (TUR) \\
\hline Switzerland, Norway, Iceland, Liechtenstein, Ukraine, Belarus, \\
New Zealand (RAX)
\end{tabular}




\subsection{Electricity and energy intensities of industrial sectors}

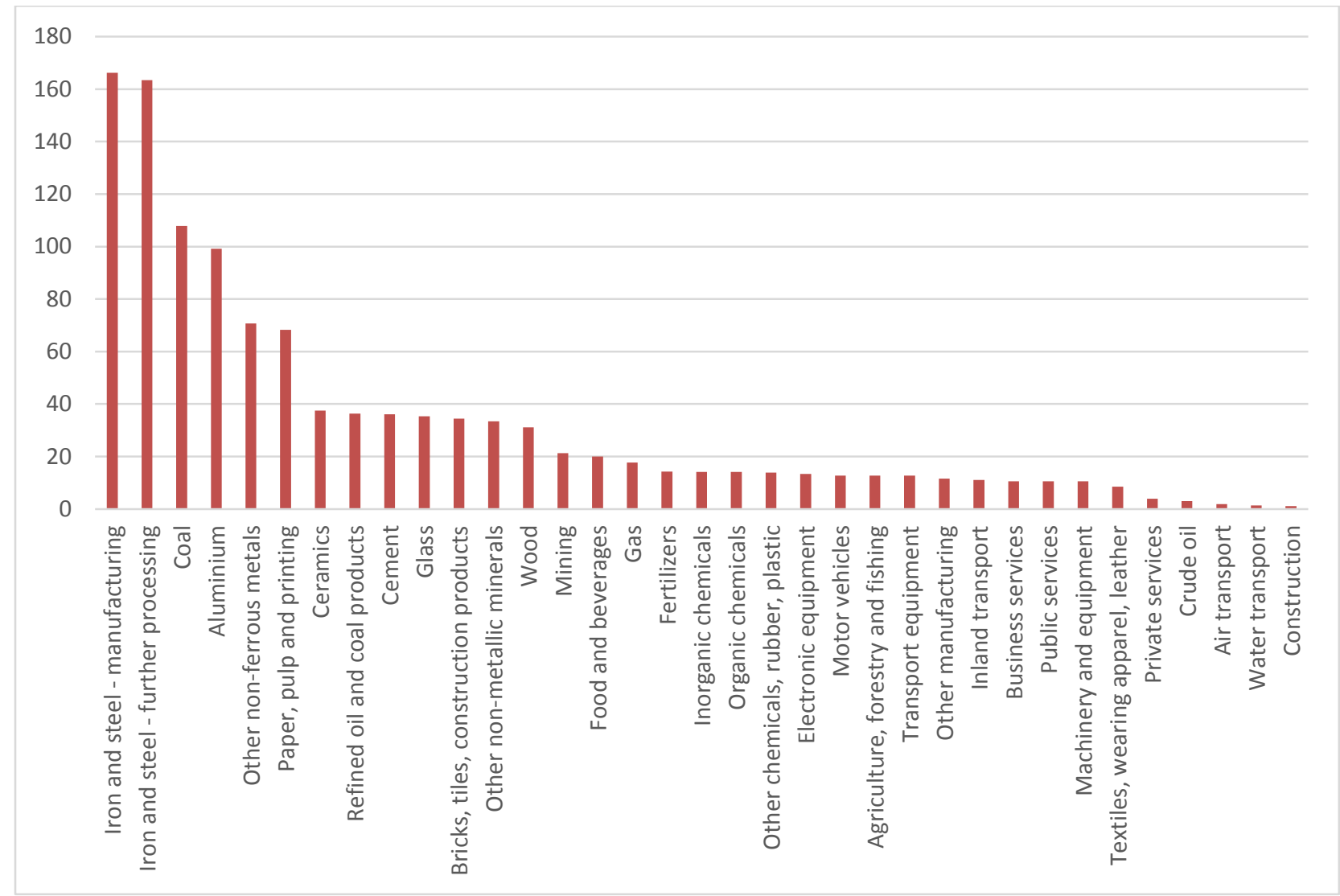

Figure 4: Electricity intensity of model sectors (toe/M€) for the baseline scenario in 2010 


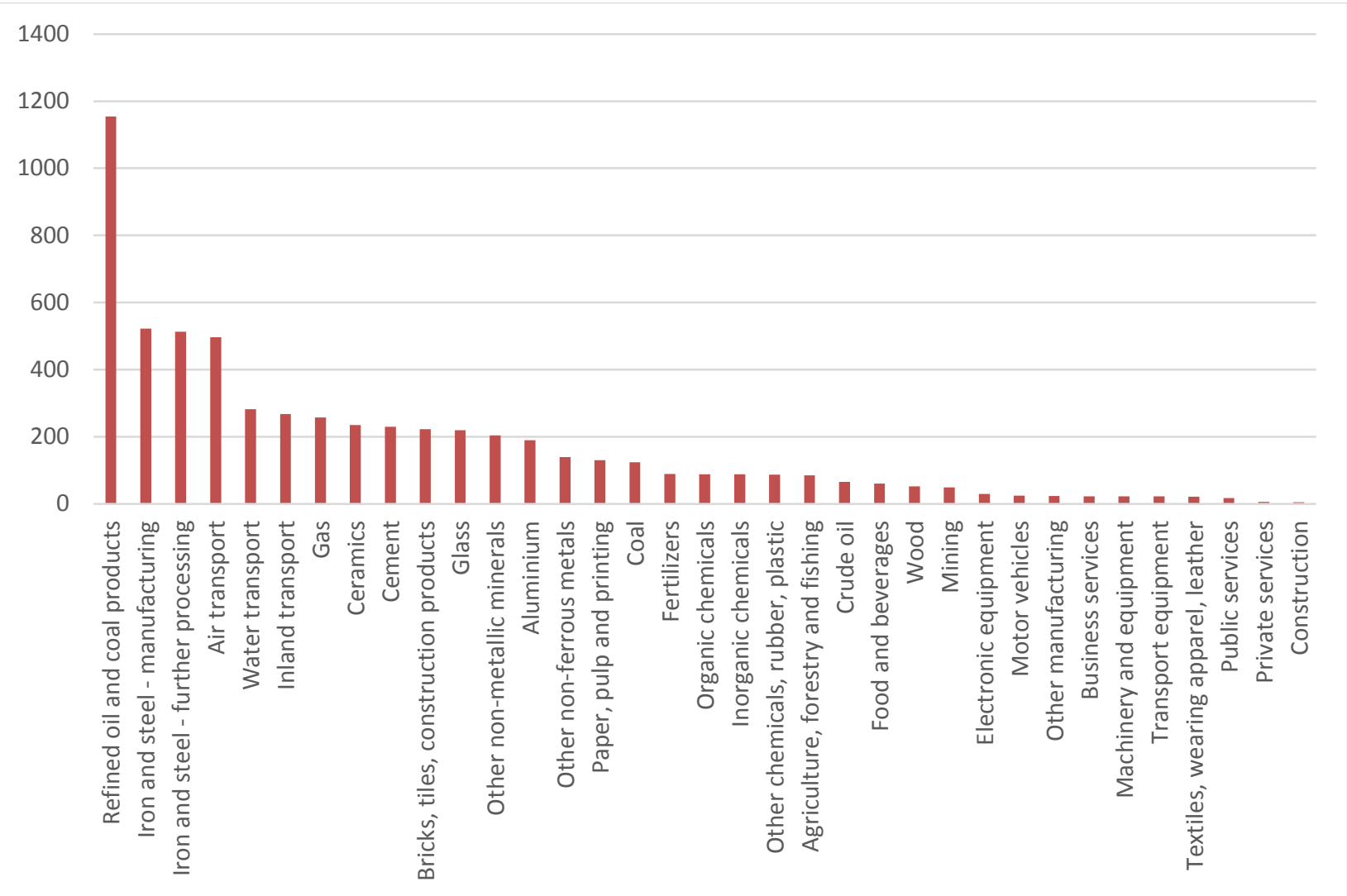

Figure 5: Energy intensity of model sectors (toe/M€) for the baseline scenario in 2010 


\subsection{Detailed sectoral results}

Table 12: Sectoral output for the EU28 aggregate in 2030 (\% change vs. baseline)

\begin{tabular}{|c|c|c|c|c|c|}
\hline Sectoral output (\% change vs. baseline) & 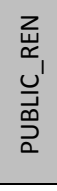 & 氶 & 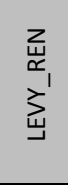 & 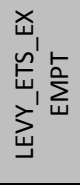 & 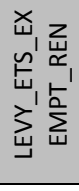 \\
\hline Agriculture, forestry and fishing & 0.0 & -0.2 & -0.1 & -0.3 & -0.1 \\
\hline Coal & 0.0 & 0.3 & 0.2 & 0.1 & 0.1 \\
\hline Crude oil & 0.0 & -0.3 & -0.2 & -0.3 & -0.2 \\
\hline Gas & 0.0 & -0.1 & 0.0 & -0.8 & -0.4 \\
\hline Mining & 0.0 & -0.7 & -0.4 & -0.5 & -0.3 \\
\hline Paper, pulp and printing & 0.0 & -0.3 & -0.1 & 0.1 & 0.1 \\
\hline Refined oil and coal products & 0.0 & -1.6 & -0.9 & -1.2 & -0.7 \\
\hline Fertilizers & 0.0 & -0.7 & -0.3 & -0.5 & -0.3 \\
\hline Organic chemicals & 0.0 & -0.6 & -0.3 & -0.2 & -0.1 \\
\hline Inorganic chemicals & 0.0 & -0.5 & -0.2 & -0.2 & -0.1 \\
\hline Cement & 0.0 & -0.3 & -0.1 & 0.1 & 0.0 \\
\hline Bricks, tiles, construction products & 0.0 & -0.3 & -0.2 & 0.1 & 0.1 \\
\hline Glass & 0.0 & -0.3 & -0.2 & 0.2 & 0.1 \\
\hline Ceramics & 0.0 & -0.4 & -0.2 & 0.1 & 0.1 \\
\hline Iron and steel - manufacturing & 0.0 & -0.9 & -0.5 & 0.3 & 0.1 \\
\hline Iron and steel - further processing & 0.0 & -1.1 & -0.6 & 0.6 & 0.3 \\
\hline Aluminium & 0.0 & -2.3 & -1.4 & 0.5 & 0.1 \\
\hline Other non-ferrous metals & 0.0 & -1.6 & -0.9 & 0.4 & 0.1 \\
\hline Air transport & 0.0 & 0.2 & 0.1 & 0.3 & 0.2 \\
\hline Electricity & 0.0 & -4.9 & -2.9 & -4.6 & -2.8 \\
\hline Food and beverages & 0.0 & -0.1 & 0.0 & -0.2 & -0.1 \\
\hline Textiles, wearing apparel, leather & 0.0 & 0.3 & 0.2 & 0.0 & 0.1 \\
\hline Wood & 0.0 & -0.3 & -0.2 & -0.5 & -0.3 \\
\hline Other chemicals, rubber, plastic & 0.0 & -1.0 & -0.5 & -1.2 & -0.7 \\
\hline Other non-metallic minerals & 0.0 & -1.0 & -0.5 & -1.2 & -0.6 \\
\hline Electronic equipment & 0.0 & -0.2 & -0.1 & -0.4 & -0.2 \\
\hline Machinery and equipment & 0.0 & -0.1 & -0.1 & -0.2 & -0.1 \\
\hline Motor vehicles & 0.0 & -0.1 & -0.1 & -0.1 & -0.1 \\
\hline Transport equipment & 0.0 & 0.0 & 0.0 & -0.1 & 0.0 \\
\hline Other manufacturing & 0.0 & -0.2 & -0.1 & -0.1 & -0.1 \\
\hline Construction & 0.0 & 0.0 & 0.0 & 0.0 & 0.0 \\
\hline Inland transport & 0.0 & -0.5 & -0.3 & -0.6 & -0.3 \\
\hline Water transport & 0.0 & -0.4 & -0.2 & -0.5 & -0.3 \\
\hline Business services & 0.0 & -0.1 & 0.0 & -0.1 & -0.1 \\
\hline Private services & 0.0 & 0.1 & 0.1 & 0.1 & 0.1 \\
\hline Public services & 0.0 & 0.0 & 0.0 & 0.0 & 0.0 \\
\hline
\end{tabular}




\section{REFERENCES}

Alexeeva-Talebi, V., C. Böhringer, A. Löschel and S. Voigt (2012). The Value-Added of Sectoral Disaggregation: Implications on Competitive Consequences of Climate Change Policies, Energy Economics, 34, Supplement 2, S127-S142.

Amdur, D., B. G. Rabe, C. Borick (2014). Public views on a carbon tax depend on the proposed use of revenue - A report from the national surveys on Energy and Environment. Issues in Energy and Environmental Policies, 13

Armington, P.S. (1969). A theory of demand for products distinguished by place of production. IMF Staff Papers 16: 159-178.

Ballard, C.L., S.G. Medema (1993). The marginal efficiency effects of taxes and subsidies in the presence of externalities: A computational general equilibrium approach, Journal of Public Economics, 52, 199-216.

Böhringer, C., Löschel, A., Moslener, U. and T.F. Rutherford (2009). EU Climate Policy Up to 2020: An Economic Impact Assessment, Energy Economics, 31 (S2): 295-305.

Böhringer, C., F. Landis and M.A.Tovar Reaños (2017). Cost-effectiveness and incidence of renewable energy promotion in Germany, ZEW Discussion Paper No. 17-004.

Bovenberg, A.L., L.H. Goulder (1996). Optimal environmental taxation in the presence of other taxes: general-equilibrium analyses, American Economic Review, 86 (4): 985-1000.

Bristow, A.L, M.Wardman, A.M.Zanni, P.K.Chintakayala, 2010. Public acceptability of personal carbon trading and carbon tax, Ecological Economics, 69(9), 1824-1837.

EC [European Commission] (2016). EU Reference Scenario 2016. Energy, transport and GHG emissions Trends to 2050.

EC (2015). Energy Union Package. Communication from the Commission to the European Parliament, the Council, the European Economic and Social Committee, the Committee of the Regions and the European Investment Bank. A Framework Strategy for a Resilient Energy Union with a Forward-Looking Climate Change Policy. COM (2015) 80 final.

EC (2014a). Communication from the Commission to the European Parliament, the Council, the European Economic and Social Committee and the Committee of the Regions. A policy framework for climate and energy in the period from 2020 up to 2030. COM(2014) 15 final.

EC (2014b). Impact Assessment accompanying the document Communication from the Commission to the European Parliament, the Council, the European Economic and Social Committee and the Committee of the Regions. A policy framework for climate and energy in the period from 2020 up to 2030. SWD(2014) 15 final.

EC (2010). Commission Regulation (EU) No 1031/2010 of 12 November 2010 on the timing, administration and other aspects of auctioning of greenhouse has emission allowances pursuant to Directive 2003/87/EC of the European Parliament and of the Council establishing a scheme for greenhouse gas emission allowances trading within the Community.

EU (2018a). Regulation (EU) 2018/842 of the European Parliament and of the Council of 30 May 2018 on binding annual greenhouse gas emission reductions by Member States from 2021 to 2030 contributing to climate action to meet commitments under the Paris Agreement and amending Regulation (EU) No 525/2013.

EU (2018b). Directive (EU) 2018/410 of the European Parliament and of the Council of 14 March 2018 amending Directive 2003/87/EC to enhance cost-effective emission reductions and low-carbon investments, and Decision (EU) 2015/1814. 
EU [European Union] (2009). Decisions adopted jointly by the European Parliament and the Council. Decision No 406/2009/EC of the European Parliament and of the Council of 23 April 2009 on the effort of Member States to reduce their greenhouse gas emissions to meet the Community's greenhouse gas emission reduction commitments up to 2020 .

EU (2003). Directive 2003/87/EC of the European Parliament and of the Council of 13 October 2003 establishing a scheme for greenhouse gas emission allowance trading within the Community and amending Council Directive 96/61/EC.

E3MLab and IIASA (2016). Technical report on Member State results of the EUCO policy scenarios.

Gurgel, A.C., S.Paltsev, J. Reilly and G. Metcalf (2011). An analysis of US greenhouse cap-andtrade proposals using a forward-looking economic model, Environment and Development Economics, 16(2): 155-176.

Harrison K. (2010). The comparative politics of carbon taxation, Annual Review of Law and Social Science, 6: 507-529.

Heres, D.R., S. Kallbekken (2015). The role of budgetary information in the preference for externality-correcting subsidies over taxes: a lab experiment on public support, Environmental and Resource Economics, 66(1), 1-15.

Horridge, M. (2008), SplitCom: Programs to disaggregate a GTAP sector, Centre of Policy Studies, Monash University, Melbourne, Australia.

ICAP [International Carbon Action Partnership] (2018). Emissions Trading Worldwide: Status Report 2018, ICAP, Berlin.

IEO (2013). International Energy Outlook. US Energy Information Administration (EIA), Washington, DC, USA. http://www.eia.doe.gov/oiaf/ieo/

Kallbekken, S., M. Aasen (2010). The demand for earmarking: results from a focus group study. Ecological Economics, 69: 2183-2190.

Kallbekken, S., S. Kroll, T.L. Cherry (2011). Do you not like Pigou, or do you not understand him? Tax aversion and revenue recycling in the lab, Journal of Environmental Economics and Management, 62: 53-64.

Marcantonini, C., A.D. Ellerman (2015). The implicit carbon price of renewable energy incentives in Germany. The Energy Journal, International Association for Energy Economics, 4 (36).

Nordhaus, W.D. (1993). Optimal greenhouse-gas reductions and tax policy in the 'DICE' model, American Economic Review, (Papers and Proceedings), 83(2): 313-17.

United Nations (2015). Paris Agreement.

Vollebergh, H.R.J., J.L De Vries, P.R.Koustaal (1997). Hybrid carbon incentive mechanisms and political acceptability, Environmental and Resource Economics, 9 (1), 43-63.

WIOD (2012). World Input Output Database. http://www.wiod.org/new_site/home.htm World Bank and Ecofys (2018). State and Trends of Carbon Pricing 2018 (May), by World Bank, Washington, DC. Doi: 10.1596/978-1-4648-1292-7. 